\title{
Assessing Brazilian Educational Inequalities
}

\author{
Benoit Lorel*
}

Contents: 1. Introduction; 2. The Standard Earning Function and Empirical Implications; 3. Empirical Assessment of Brazilian Educational Inequality; 4. Look Beyond the Average and Consequences on Brazilian Wage Inequality; 5. Conclusion; A. Indicators used to quantify Education; B. Desirable Properties of the Inequality Indices; $C$. Tables.

Keywords: Human Capital, Education Gini, Inequality

JEL Code: C43, D63, I32, J24, 011, 015

Esse trababalho busca avaliar o grau de desigualdade educacional no Brasil baseado-se em diferentes indicatores tais como: o índice de Gini educacional, os anos médios de escolaridade e no desvio padrão educacional. Tenta-se colocar uma descrição estatistica da distribuição do capital humano no Brasil, incluindo as diferenças estaduais e regionais observadas durante a ultima metade do século. As conclusões da nossa análise são as seguintes: 1) Forte reduç ão das desigualdades educativas calculadas com o Gini educacional. 2) Um retrato tripartido do Brasil parece se formar refletindo as condições iniciais. 3) Um forte aumento dos níveis de escolarização. 4) Uma relação significativa entre o Gini educacional e os anos médios de estudos. 5) O desvio padrão educacional leva aos resultados inversos do Gini educacional. 6) Os dados brasileiros admitem uma curva de Kuznets educacional se considerarmos o desvio padrão educacional.

This paper provides an evaluation of schooling inequality in Brazil using different indicators such as the Education Gini coefficient, the Education Standard Deviation and the Average number of Years of Schooling. We draw up a statistical description of Brazilian human capital dispersion in time over the last half century, across regions and states. Our analysis suggests several conclusions: 1) Strong reduction of educational inequalities measured by Education Gini index. 2) A three parts picture of Brazil seems to emerge, reflecting initial conditions. 3) High increase of the Average number of Years of Schooling. 4) A significant link between Education Gini and the average education length. 5) Education Standard Deviation leads to inverted results compared to Education

*I am grateful to Universidade Santa Ursula for hospitality and to Jean Mercenier and an anonymous referee for helpful comments. Usual disclaimers apply. Université de Cergy-Pontoise, 33 bld du Port 95011 Cergy-Pontoise Cedex, France. Phone: (33) 134257231 ; Fax: (33) 134256233 ; Benoit.Lorel@eco.u-cergy.fr; THEMA - UMR CNRS 8184 - Université de Cergy-Pontoise. 
Gini. 6) Brazilian data are consistent with an Education Kuznets curve if we consider Education Standard Deviation.

\section{INTRODUCTION}

As is well established, ${ }^{1}$ the transmission of schooling across generations is the key channel by which schooling inequality affects income inequality. The hope that improvements in overall access to schooling by one generation will reduce social inequalities lies not only in the potential reductions in earnings inequality for that generation, but also in potential improvements in the distribution of education for that generation's children. The contribution of schooling in explaining earnings inequality comes from two components - high dispersion in the distribution of schooling and large effect of schooling on earnings. Various authors have shown ${ }^{2}$ that there is an important element of inertia in the evolution of schooling distributions and income distributions in developing countries. An accurate measure of the schooling dispersion within a country appears extremely useful both for positive and normative reasons. To see this, consider an asset freely traded in a perfectly competitive environment with freeentry: equalization of marginal productivities across firms will be ensured. Introduce imperfection in that market: marginal products are not equalized and an aggregation problem follows. The aggregate production function will depend not only on the average level of the asset, but also on its distribution. Because education is not perfectly tradable, the average level of schooling achievement of a country is not sufficient to reflect its human capital characteristics. We need to look beyond the average and thus have to investigate the dispersion of human capital. ${ }^{3}$ Surprisingly, at the best of our knowledge, no such studies seem to have been made for Brazil. Our aim in this paper is to contribute to fill this gap: we provide an evaluation of schooling inequality in Brazil using different indicators such as the Education Gini Coefficient, the Education Standard Deviation and the Average number of Years of Schooling. We are able to cartography schooling disparities, we investigate evolutions, extract some stylized facts, assess the consequences of the political reforms on education and venture some suggestions on most appropriate policies depending on regions and their development. Brazil provides us a very interesting case on more than one respect. First, its educational system has been drastically changed during the second half of the 20th century and particularly during the 90s with explicit commitment of the Brazilian government in providing schooling to all. Although, large efforts were effective, there still remains room for improvement on many respects: ${ }^{4}$ access to education, reception capacity in schooling and university establishments, education quality, education equity between the various social groups and educational intergenerational mobility. ${ }^{5}$ The Brazilian case is also relevant from an economic theory on inequalities viewpoint. Until the 1980s, Brazil had considerable success with economic growth: ${ }^{6}$ its average growth rate was of $4,7 \%$ during the twentieth century (with growth concentrated in the south of the country and more particularly in regions Sul and Sudeste). Despite this remarkable performance,

\footnotetext{
${ }^{1}$ Following the Endogenous Growth Theory, we note at least 4 main reasons for a negative relation between inequality and economic growth. 1) Increase in redistribution and fiscal pressure in line with political economics models (Benabou, 1996, Alesina and Rodrik, 1994, Alesina and Perotti, 1996, Saint-Paul and Verdier, 1993), 2) Sociopolitical tensions (Acemoglu, 1995, Benhabib and Rustichini, 1996), 3) Credit rationing (Galor and Zeira, 1993, Aghion and Bolton, 1997) and 4) Fertility (Becker and Barro, 1988, Becker et al., 1990, Galor and Moav, 2002).

${ }^{2}$ See for instance Lam (1999).

${ }^{3}$ See Appendix for a refresher on indicators proposed to quantify alternative aspects of education.

${ }^{4}$ See Barros and Mendonça (1998) concerning impact of educational reforms.

${ }^{5}$ Ferreira (2003) shows that Brazilian educational intergenerational mobility is weaker than in other developing countries and that it differs considerably between states, between regions and between races. For instance, in region Nordeste, the probability that the son of uneducated parents remains uneducated is approximately $54 \%$, while the same probability is "only" $21 \%$ in region Sudeste.

${ }^{6}$ See for instance Maddison and Associates (1992).
} 
social indicators in Brazil remain those of a poor country actually doing worse in terms of income inequality than most developing countries. ${ }^{7}$ In addition, Bowman (1997) shows that a continuous rise of income inequality occurred in Brazil despite of the increasing income per capita above the Kuznets inflection threshold of $\$ 1200$ usually observed.

How does Brazil generate such extreme income inequalities, among the highest in the world? Does current patterns of educational inequalities tell us anything about the prospects for reducing inequalities in future generations? We shall try to provide some elements of response to these questions in this paper.

The paper is organized as follows. Section two establishes the importance of education in Brazilian wage dermination and provides a brief presentation of our methodology. In the third section, we evaluate spatial and temporal Brazilian educational inequality. Section four establishes links between indicators and implications of education inequelities on earnings inequalities. A fifth section concludes.

\section{THE STANDARD EARNING FUNCTION AND EMPIRICAL IMPLICATIONS}

\subsection{Education as a Wage Determination Factor in Brazil}

The link between education and the distribution of income has been a fundamental building block of economics of inequality. ${ }^{8}$ Theoretical models and extensive empirical evidence highlight the role of schooling explaining the distribution of income. Our analysis below will focus on inequality in individual labor earnings, for which the importance of schooling should be more easily observed.

A useful frame of reference is the standard human capital earnings equation. Leaving experience and other factors aside, the logarithm of individual $i$ 's labor earning can be expressed as:

$$
\log y_{i}=\alpha+\beta e_{i}+u_{i}
$$

where $y_{i}$ is earning, $e_{i}$ the number of years of schooling, and $u_{i}$ is a random term uncorrelated with schooling. To avoid pitfalls in time-series econometrics with incomplete data or unstable definition, we estimate this human capital earning equation by cross-section for the year 2000 using IBGE data. ${ }^{9}$

The data relate the education level (6 groups: from 0 to "15 years and more") with the income group (12 groups based on a minimum wage of 151RS: from 0 to "more than 30 times as minimum wage"). Note more than $60.05 \%$ of Brazilian earn less than the minimum wage and more than $64.7 \%$ have less than seven years of education.

The estimation results are presented in Table $1 .^{10}$ Group $e 2$, with individuals having between 4 and 7 number of years of schooling, serves as reference group in this regression, so that coefficients should be interpreted measuring the differential return to education to that group. We see that education alone explains $87.8 \%$ of wages for the country as a whole, with the lowest $R$-square is quite low for region Sul, where it is yet as high as $69.9 \%$. In a nutshell, this regression expresses forcefully the strong link that exists between education and wage earnings and justifies the current empirical assessment of the performances in term of education progress.

\subsection{Earning Inequality and Education Inequality}

The influence of educational inequalities and income inequalities, from standard earnings equation, the variance of log earnings, $V(\log \quad y)$, a standard mean-invariant measure of earnings inequality, is:

\footnotetext{
${ }^{7}$ See Barros et al. (2002) for impact of an additional year of schooling on income per capita growth rate.

${ }^{8}$ See for instance Blom et al. (2001) for a Brazilian study.

${ }^{9}$ Demographic Census 2000.

${ }^{10}$ See in Appendix.
} 


$$
V(\log y)=\beta^{2} V(e)+V(u)
$$

This simple result demonstrates an important point about the link between schooling inequality and earnings inequality. If the relationship between schooling and earnings is log-linear as in traditional earnings equation above, then earnings inequality is a linear function of the variance in schooling. While there is intuitive appeal to the notion that a more equal distribution of schooling should reduce a more equal distribution of earnings, there is no theoretical reason to expect such a result. Indeed, variance of schooling (or the Education Standard Deviation) only measures the dispersion of schooling distribution in absolute terms. If we measure inequality in schooling by some standard mean-invariant inequality measure, for instance by the coefficient of variation, then if the increase in average number of years of schooling is greater than the increase in the education standard deviation, thus a decrease in schooling inequality is associated with increased earnings inequality. Hence, to measure the relative inequality of schooling distribution, developing an indicator for Gini Education is necessary.

\subsection{The Education Gini: Measuring Inequality in the Distribution of Education Achievements}

Only few previous studies have estimated the Education Gini Index to analyze inequality of the education achievement distribution, none for Brazil to the best of our knowledge. We propose to do so, including an analysis of regions and states over the period 1950-2000.

Schooling distributions possess various characteristics which make inappropriate the use of some standard indicators. Because of these characteristics and despite its drawbacks (it does not satisfy the SI and SC conditions), ${ }^{11}$ the Gini Index singles out as the most appropriate. Indeed, it makes it possible to draw Education Lorenz curves and the related stochastic dominance approach can then be used to compare distributions. Regarding methodology, schooling achievement is a discrete variable. Furthermore, its distribution is bounded: by a lowerbound of 0 (for people who did not go to school in their entire live) and by a maximal value close to 20 years of schooling. The Education Lorenz curve is then a series of points (corresponding to the number -or group- of years of schooling of the population). It is not necessary to evaluate a continuous line to get the Education Lorenz curve. Another main feature of the Education Lorenz curve is that it is not regular due to the presence of illiterates ${ }^{12}$ (or people who never go to school (less than 1 year)): a part of this curve coincides also with the horizontal axis.

Depending on available data, the Gini formula could vary. In this paper, we make use of its distributions of population over the age of five, as provided by IBGE ${ }^{13}$ Censos Demograficos. The formula we use is the following: ${ }^{14}$

$$
\text { Gini }=\frac{1}{\bar{x}} \sum_{i=1}^{n} \sum_{j=0}^{i-1} p_{i}\left|x_{i}-x_{j}\right| p_{j}
$$

where

- $p_{i}, p_{j}$ are proportions of population respectively with $i$ and $j$ years of schooling

- $x_{i}, x_{j}$ are numbers of completed schooling years

\footnotetext{
${ }^{11}$ See Appendix for a refresher on desirable properties of inequality indices.

${ }^{12}$ Which makes inappropriate the use of the Theil index.

${ }^{13}$ i.e. Instituto Brasileiro de Geografia e de Estatistica (Brazilian Institute of Geography and Statistics)

${ }^{14}$ This expression has been also used by Thomas et al. (2001).
} 
- $n$ represents the number of schooling achievement levels

- $\bar{x}=\sum_{i=0}^{n} p_{i} x_{i}$ is the average number of years of schooling of the population

The Education Lorenz curve is obtained as follows. The horizontal axis represents the cumulative proportion of population $Q_{x}$ with less than $x$ years of training: $Q_{0}=p_{0}$, corresponds to the proportion of people with less than 1 year in school, $Q_{1}=p_{0}+p_{1}$ is the proportion of the population with less than 2 years of schooling etc. The vertical axis refers to $S_{x}$, the cumulative proportion of population that has at least reached a specified level of education. Hence, $S_{0}=\frac{p_{0} x_{0}}{\bar{x}}=0, S_{1}=\frac{p_{0} x_{0}+p_{1} x_{1}}{\bar{x}}$ etc.

Figure 1 provides a rough international comparison ${ }^{15}$ of progress achieved in terms of human capital Gini coefficient between 1960 and 1985. The panel of countries include both developed and developing countries. We first note that Education Gini in developed countries is much weaker than in developing ones. While Brazil remains in the group of highest Education Gini together with Mexico during the considered period, some countries such as Korea have remarkably managed to decrease their Education Gini. For Korea, this index was as high in the 60s as it was in Brazil, yet as low as France twenty five years later. Incidentally, observe that France and US strongly have very different trends.

Figure 1 - International Trend of Education Gini

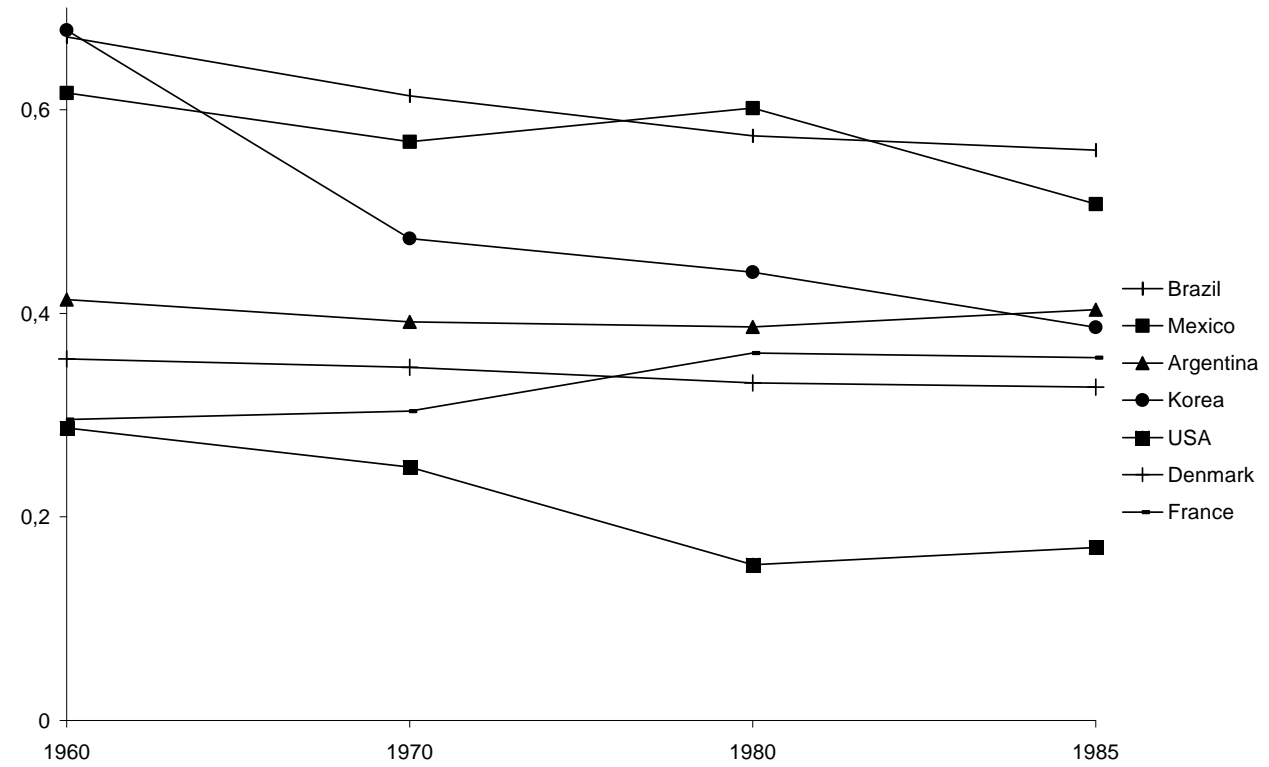

${ }^{15}$ We use Barro and Lee's data set. 


\section{EMPIRICAL ASSESSMENT OF BRAZILIAN EDUCATIONAL INEQUALITY}

Using the IBGE data on educational achievement for people over five, ${ }^{16}$ measured in completed schooling year, ${ }^{17}$ we compute the Education Gini index, as well as the Average number of Years of Schooling (AYS) and the Education Standard Deviation (ESD) for Brazil as a whole, for rural and urban, for the 5 regions (Norte, Nordeste, Sudeste, Sul and Centro-Oeste) and for the various states over the period 1950-2000. Our data set then includes 27 states with a total around 2700 observations. We can then analyze Brazilian educational inequality changes for the last half century. Among others, we find many states that in spite of having the same AYS, significantly differ in the distribution of education.

\subsection{Trend of Education Gini}

Using distribution of population for each education year, we estimate the Education Gini over 19502000. The detailed results are reported in Table $2{ }^{18}$ We comment on the results and provide some graphs.

There is a clear downward convergence between regions and states. Furthermore, the reduction of educational inequalities is impressively strong for all regions. The decline is not monotonous; however, education inequality increased slightly during the 1960s. ${ }^{19}$ The first Brazilian ten-year plan for education was formulated in 1967, and it brought about a massive expansion of enrollments.

Examining the results for the country as a whole first, we observed that the Education Gini coefficient has sharply declined from $1950(0,7868)$ to $1960(0,6246)$, followed by a short increase during the 60 s to reach 0,6485 in 1970 ; since the early 70 s, the Education Gini has monotonically decreased reaching 0,4031 in 2000. On the whole half century, Brazilian education inequalities have decreased by $48,77 \%$, with an acceleration during the last ten years. That decrease may be explain by various Brazilian education reforms. Indeed, 1971 Education Law extended the length of compulsory school from four to eight years. Moreover, the Brazilian education system has been gradually shifting the responsibility for delivering and managing education at primary level from the central government (Federal level) to the states and municipalities. 1988 Brazilian Constitution has increased the states' and municipalities' participation in the decision making process of educational policies. ${ }^{20}$

In Figure 2, we report time series of the Brazilian Education Lorenz curve. The interpretation of this graph is identical to that of the Income Lorenz curve and describes the sharing of education among population. We see that in 2000 , more than $10 \%$ of the population receive no education at all while $33,4 \%$ received only $7,2 \%$ of total cumulated years of schooling. In contrast in $1950,67 \%$ of the population did not receive any education, while $72 \%$ owned only $3,7 \%$ of the education capital.

Despite the decentralization in the making process educational policies, the same trend can be observed for all regions within Brazil. Furthermore, there is a clear convergence of performance between regions, as measured by the variance of Education Gini or by the difference. It mainly occurs however, between 1990 and 2000.

As could probably be expected, Region Nordeste ${ }^{21}$ remains on the whole period the region with the highest Education Gini index, despite strong progress (particularly during the last ten years: 28,64\%).

\footnotetext{
${ }^{16}$ We have used the educational information for the population aged 5 and over for emphasizing the importance of improve in primary education access in Brazilian population, than most related studies use the information of the education for the population aged 25 years and over.

${ }^{17}$ For instance, Barro and Lee's data set only includes the schooling level: No schooling, primary completed or uncompleted, secondary completed or uncompleted and at least tertiary completed or uncompleted.

${ }^{18}$ See in Appendix.

${ }^{19}$ Note a different trend compared with Barro and Lee's data, but IBGE data seem to be more complete and precise.

${ }^{20}$ See Barros and Mendonça $(1997,1998)$ for further details.

${ }^{21}$ From 0,9018 to 0,4856 .
} 
Figure 2 - Education Lorenz Curve - Brazil 1950-2000

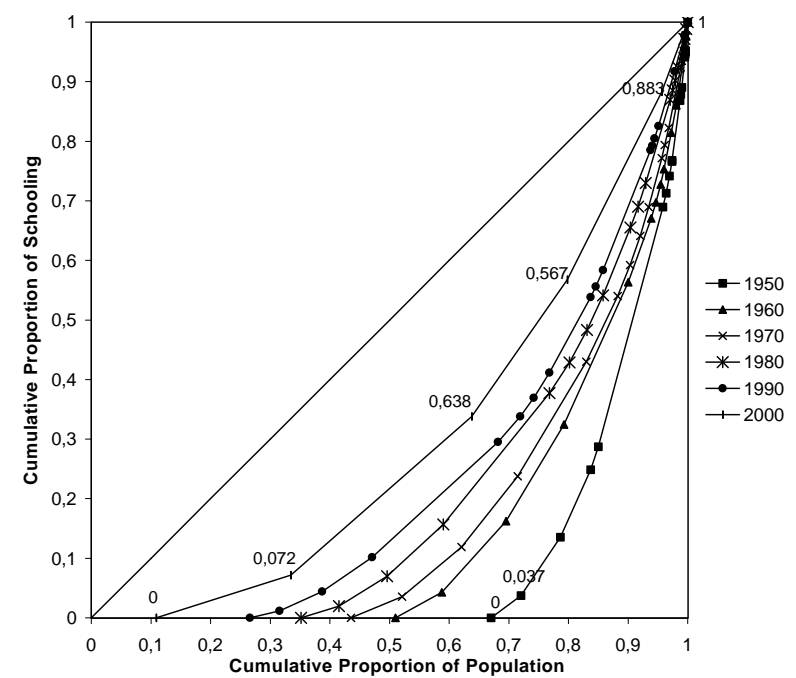

Region Centro-Oeste (in 1950), Sudeste (in 1960) and Sul (from 1970) are the most egalitarian regions. Between 1950 and 2000, Regions Sudeste and Centro-Oeste achieved respectively the highest and the weakest progress: $-51 \%$ and $-43 \%$.

Region Centro-Oeste is also the most heterogeneous region (with the highest standard deviation across Education Gini index: 0,19 in 1950 and 0,05 in 2000), while regions Sul and Sudeste are the most homogeneous (standard deviation of 0,01 for region Sul in 2000). Indeed, Region Centro-Oeste is worth noting in many respects. This Region takes advantages of the political and administrative status of Distrito Federal and State of Goias makes the most of the situation.

The Case of Goias (see Figure 3) is noteworthy. Indeed, starting from a terrible initial situation with $85,32 \%$ of the population without education in 1950 , Goias expanded its basic education rapidly and eliminated illiteracy successfully and after half a century this population represent only $9,26 \%$ corresponding to the average of Centro-Oeste $(9,38 \%) .{ }^{22}$ Over decades, the Education Gini decreased by $58 \%$ ( $42,7 \%$ for Region Centro-Oeste and $48,77 \%$ for Brazil as a whole).

To conclude with the Education Gini index, Region Centro-Oeste contains an historical and political exception (Distrito Federal) and the development of Goias. In region Nordeste lies bad permanence feature and homogeneity, whereas Sul and Sudeste are the most homogeneous and perform the highest decreasing rate of Gini.

\subsection{Dropping Out No Schooling: What remains of Educational Inequality}

Previous results have documented a strong reduction of educational inequality in Brazil since 1950. However a more careful look at those results is called for: indeed, if we drop from our sample those

${ }^{22}$ See in Appendix Table 6 on the population with no schooling to compared to other states within the Centro-Oeste. 
Figure 3 - Education Lorenz Curve - Goias - 1950-2000

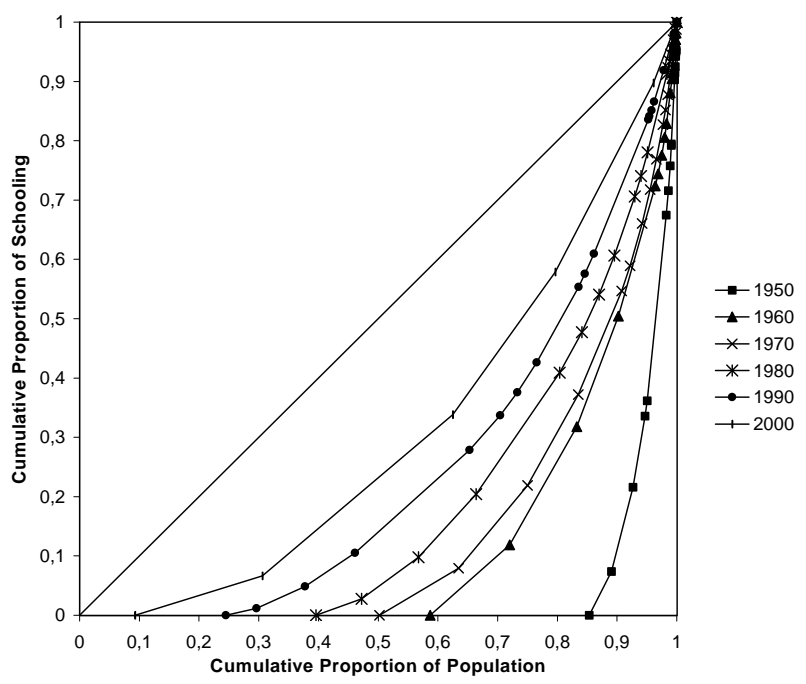

members of the population that are without any education, the results, regarding the evolution of the Education Gini are extremely different, as shown by Table $3 .^{23}$

No trend is apparent in the latter series, which clearly reveals that progress has been achieved primarily by universalization of basic education. ${ }^{24}$

Regional rankings remains however broadly unaffected. There are exceptions of course: the performance of the Region Nordeste, measured as the rate of decline of the Education Gini, is the lowest with $4,24 \%$, while it was the highest when considering the whole population. Note that one more time, the Centro-Oeste benefits more than other regions of the reduction of inequality from 1970.

Concerning states, note that Goias performs in the second best place $(-19,42 \%)$ and note that is the only state where we observe an increase of educational inequality measured by the Education Gini.

We take a closer look at the progress achieved, measured by the proportion of population unexposed to basic education ${ }^{25}$. Progress has been considerable.

Observe that Figure 4 singles out some regions (Nordeste and Sul) and some States (Goias, Santa Catarina and Maranhão). On average for the country, non-educated people represented $67 \%$ of total population in 1950 , a proportion that has fallen to $11 \%$ today. Needless to say, this remarkable aggregate performance makes strong regional disparities, even though all regions have indeed followed the same trend evolution. Noteworthy is the case of Nordeste which is the region that shows the steepest negative trend despite with the highest proportion of non-educated.

\footnotetext{
${ }^{23}$ See in Appendix.

${ }^{24}$ Since 1988 Brazilian Constitution, Universal primary education appears the major objective of successive governments.

${ }^{25}$ See Table 4 in Appendix
} 
Figure 4 - Trend of Brazilian with No Schooling

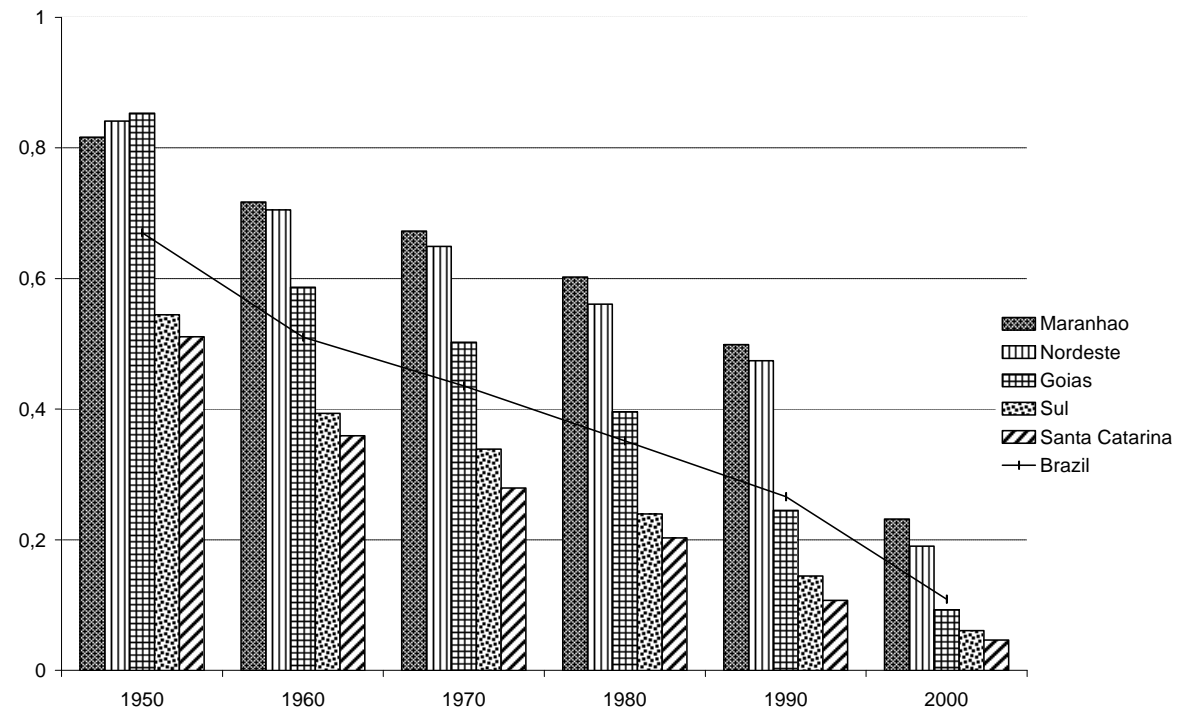

\subsection{Trend of the Average Number of Years of Schooling}

Table $5^{26}$ reports on trend of Average Number of Years of Schooling (AYS). We see that, although it remains weak compared to other relevant countries, the Brazilian AYS increases a lot during the considered period, from 1,34 reaching the level of 6,28 in 2000. Regional and state ranking is more stable through time here than was suggested by the Gini index. This is of course not a surprise since it is much more difficult to change substantially the average number of years of schooling.

Sudeste performs systematically better in terms of AYS on the considered period, except in the very beginning. This region appears quite unequal according to the AYS criterion (ranking at the second place in terms of AYS standard deviation), which was not the case when considering Education Gini. As it was already apparent from Education Gini comparison, Nordeste lags behind with an AYS of 4,8156 in 2000 even though it experienced the highest rate of increase among regions (+758\%).

The weakest performance (in terms of increasing rate) occurs in Centro-Oeste with $146 \%$. It owes his relative dynamism to Goias (with an increasing rate of $1168 \%$ between 1950 and 2000, the AYS goes from 0,5082 to 6,4421 ).

At the state level, despite the lowest increasing rate of $108 \%$, the best performance is achieved by Distrito Federal, where it is worth noting the AYS fell from 1950s to 1960s. It may correspond to the decision time which Brasilia has been designed as the Federal capital. That decreased may be related to the migration and to the civil construction labor force. Piaui stands unquestionably at the other extreme of the spectrum. Note interestingly that the trend of AYS is relatively similar between states in

${ }^{26}$ See in Appendix. 
Region Nordeste, and despite the same AYS, States of Sergipe and Bahia (respectively 1.99 and 1.91 in 1980s) incure stronger difference in Education Gini (respectively 0.73 and 0.79).

\subsection{Trend of the Education Standard Deviation}

In Table $6,{ }^{27}$ we report another measure of the educational inequalities: the Education Standard Deviation (ESD). This index is widely used presumably because it combines basic statistical and easily available measurements, even though it does not satisfy the conditions SI and DT.

It is defined as follows:

$$
E S D=\sum_{i} \sqrt{p_{i}\left(x_{i}-\bar{x}\right)^{2}}
$$

The overall picture on the evolution of educational inequalities using this statistical index is different than the one obtained from Education Gini. According to the former index, educational inequalities increase on the half century, standard deviation growing from 2,55 to 4,57 .

We make a few observations. First, there is strong convergence both between regions and between states.

Second, the most unequal regions and states are the ones with highest AYS and then Centro-Oeste and Sudeste: Distrito Federal and Rio de Janeiro are the most unequal States, however occurring with the lowest growth rate of the Education Standard Deviation on the considered period: $+24 \%$ for CentroOeste and $+17 \%$ for Sudeste.

Third, the lowest educational inequality is achieved by Nordeste (between 1950 and 1980 despite the highest growth rate on the considered period: $+156 \%$ ) and Norte (in 1990 and 2000).

Results clearly contrast with the one obtained from Education Gini. Looking carefully, Regions or states are also in inverted positions compared to the Average number of Years of Schooling.

\section{LOOK BEYOND THE AVERAGE AND CONSEQUENCES ON BRAZILIAN WAGE INEQUAL- ITY}

\subsection{Link between Education Gini and Average Number of Years of Schooling}

Examining cross-state patterns of the distribution of education, we find that Education Gini declines as the average education level increases. That is, States or Regions with higher AYS are most likely to achieve an equitable education system as can be seen from Figure 5 below. $^{28}$

This inverse relationship between Education Gini and AYS estimated from a panel is robust and found in every cross section between 1950 to 2000 .

The panel regression results, reported in Table $7,{ }^{29}$ also indicate statistically significant evidence of this negative relation, whether we use variables stacked by dates or by states or whether we control for time-specific or state-specific factors, or whether we use fixed, between or random effect models.

These results have important policy implications. They imply that moving any person out of illiteracy (or with at least one year of education) improves both education Gini and the level of education attainment. Also increasing AYS by one year reduces the Education Gini index by almost 0,0933.

\footnotetext{
${ }^{27}$ See in Appendix.

${ }^{28}$ See Table 9 in Appendix for abbreviation of states.

${ }^{29}$ See in Appendix.
} 
Figure 5 - Average Number of Years of Education - Education Gini - States - 1950-2000

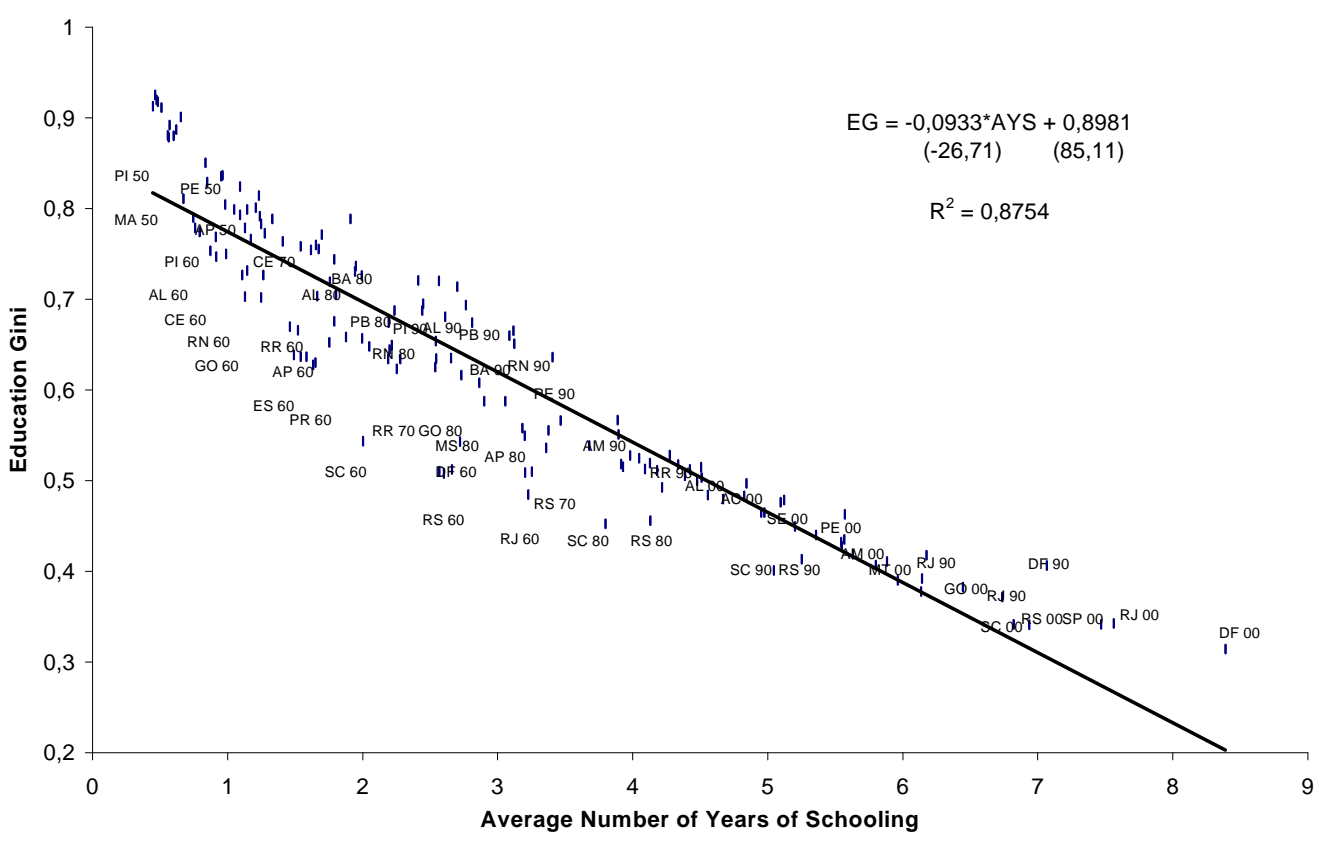

\subsection{Link between Education Standard Deviation and Average Number of Years of Schooling}

Kuznets has suggested that it is an unavoidable characteristic of the development process that income inequality should exhibit a hump-shaped profile. ${ }^{30}$ Should it also be the case for educational inequality? Is this claim confirmed by Brazilian data?

In Table $8^{31}$ and Figure 6 , we provide some econometric tests of this claim. For this, we regress Education Standard Deviation and Average number of Years of Schooling assuming either a parabolic or a $\log$ fit.

Econometric results show that this parabolic-fit is significant using Within or GLS regression (but not using a Between regression). Hence, this relation becomes significant if we consider temporal

\footnotetext{
${ }^{30}$ Kuznets (1966): "It seems plausible to assume that in the process of growth, the earlier periods are characterized by a balance of counteracting forces that may have widened the inequality in the size distribution of total income for a while because of the rapid growth of the non-A [non-agricultural] sector and wider inequality within it. It is even more plausible to argue that the recent narrowing in income inequality observed in the developed countries was due to a combination of the narrowing inter-sectoral inequalities in product per worker, the decline in the share of property incomes in total incomes of households, and the institutional changes that reflect decisions concerning social security and full employment."

${ }^{31}$ See in Appendix.
} 
Figure 6 - Average Number of Years of Education - Education Standard Deviation - States - 1950-2000

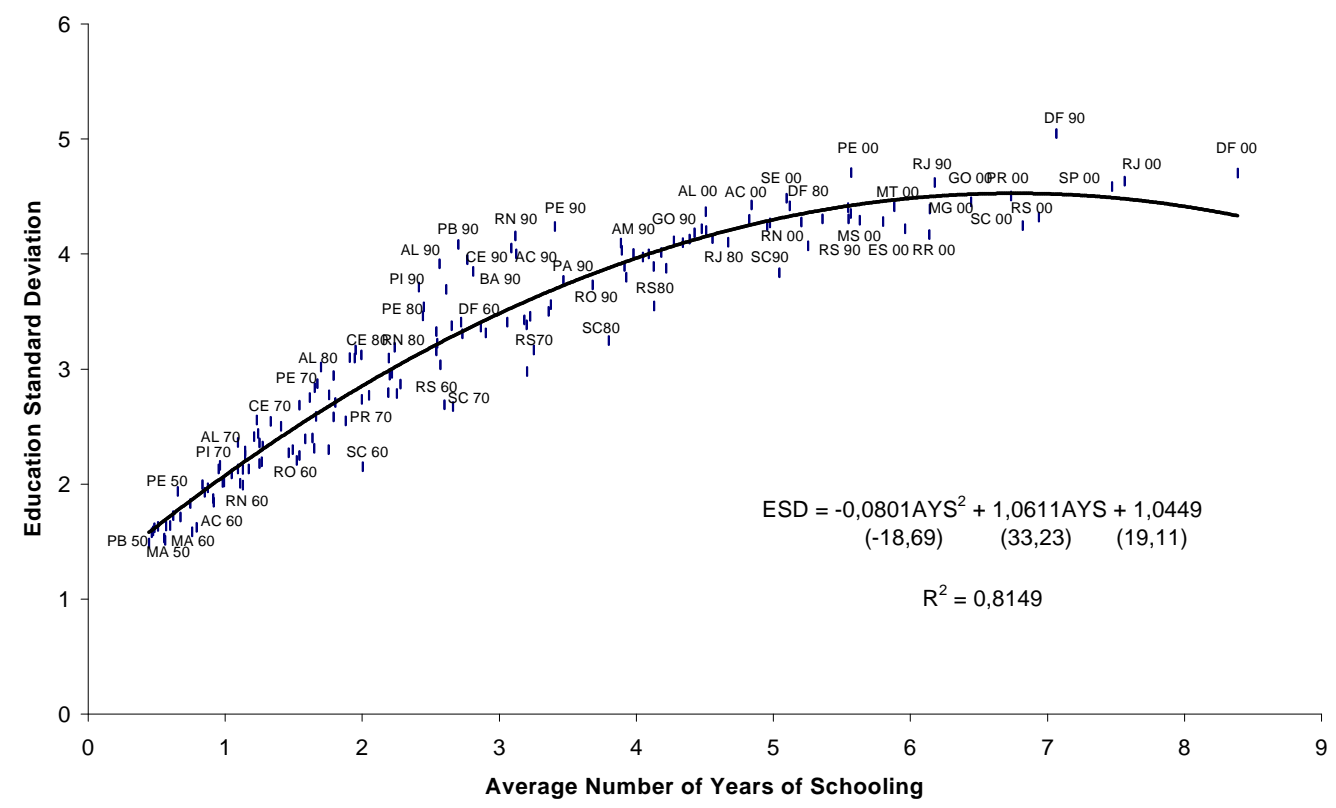

fluctuations of the States around their average level. It seems to corroborate Thomas et al. (2001). Indeed a Brazilian Educational Kuznets curve does seem to emerge from our data, with a reversal point around 6,59.

In fact from data, that reversal (inflection) point only occurs for Distrito Federal around 7 average number of years of schooling (between 1990 and 2000), as describing and should occurs soon for Rio de Janeiro, Goias (but also São Paulo) as showed in Figure 7. Concerning other states, a possible cause of that non-result may be that our temporal sample is not large enough to come across a U-Shaped inverse as the well known Kuznets curve or that Brazil is in the second phase of development, according the Education Kuznets curve.

While interpretation in logarithmic-fit is not clear (increasing Average number of Years of Schooling will infinitely increase Education inequality, measured by Education Standard Deviation), the Kuznets one is obvious.

For a state which has low schooling achievement, helping people to become educated may enlarge the Education Standard Deviation and the spread of education will be widened as people are getting higher educated.

However, for a state which already has high schooling attainment, it would have to reduce the spread of the schooling in order to raise the average level of the distribution and improve distribution.

In other words, under a set of clear cut conditions, early stages of education are characterized by 
Figure 7 - Average Number of Years of Education - Education Standard Deviation in selected States 1950-2000

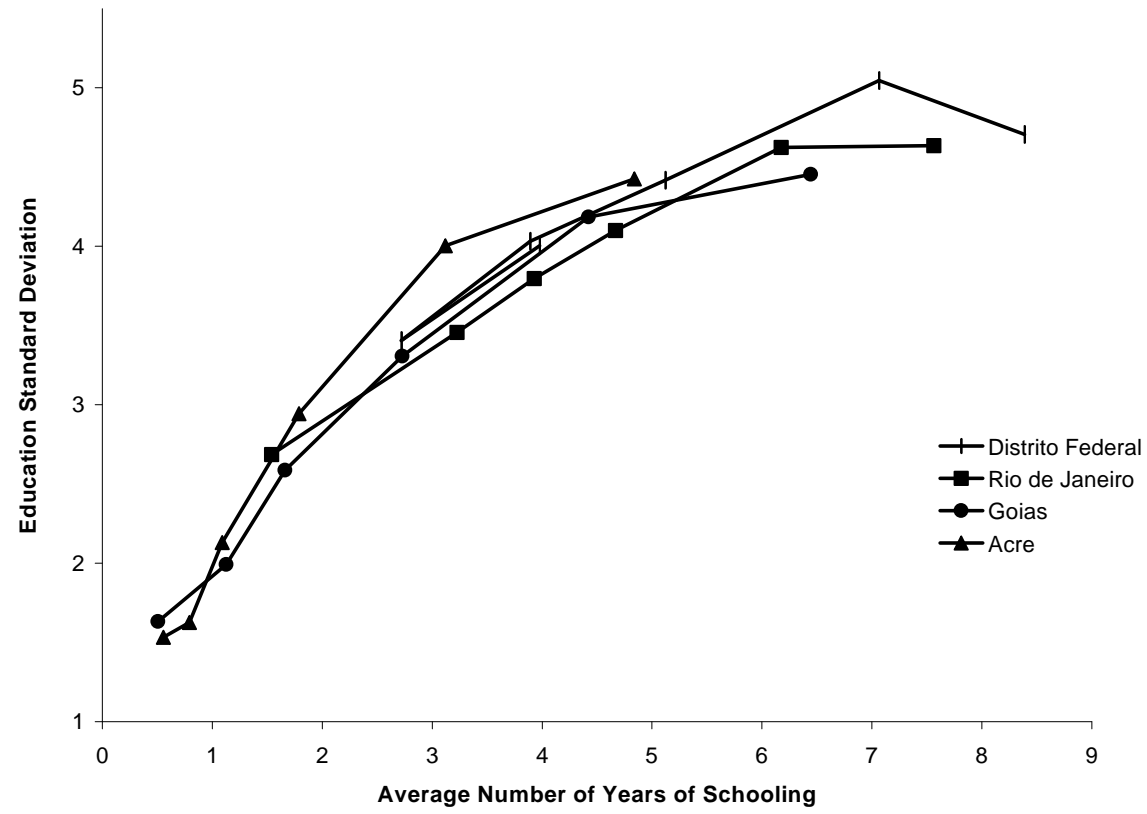

a rise in inheritance inequality because well educated people leave a bequest while the poor devote their time to work and not to education (constrained by a threshold of minimal consumption). Tradeoff between time allocated to education or work acts in favour of work for children of poor educated people. In such condition, increasing AYS can be due to the high part of the distribution, increasing such a way educational inequality.

Low educated people benefits from higher AYS as it increases. Trade-off between work and education acts now in favour of education for high and medium part of the distribution. More and more people continue one's studies. This allows them to escape from their minimal present consumption through economic and educational perspective. In later stages, a increasing AYS is mainly due to an increasing education time of the whole population. Inequality is then clearly decreasing.

A political strategy consists then to attain this threshold as soon as possible.

\subsection{Implications on Brazilian Wage Inequality}

We have highlighted the fact that results contrast according to the index used to measured educational inequalities. While the Average number of Years of Schooling is highly increasing, the Education Gini is sharply going down, when the increase in Education Standard Deviation is slowing down. 
An interesting observation should be made after comparing the behavior of Education Gini and the Education Standard Deviation. In spite of schooling achievement (i.e. rise in average number of years of schooling), helping agents to be educated on the one hand increases Education Standard Deviation, on the other hand it decreases the Education Gini coefficient value. Nevertheless, Education Gini index seems to be more robust and appropriate to study disparities in educational distribution. Indeed, whatever the average number of years of schooling, an additional educational year provoke a diminishing of the Education Gini, than in terms of Education Standard Deviation, situation calls for previously high average number of years of schooling.

Brazil's experience has resulted in periods in which reduction in schooling inequality coincided with rises in income inequality. As shown above, the variance of schooling has peaked with more recent cohorts in the country, suggesting that this component will contribute to declining earnings inequality in the future. ${ }^{32}$ Unambiguous improvements in the distribution of schooling, could lead to decreased inequality in earnings. The fundamental reason is that earnings are likely to be a convex function of schooling, the log-linear wage equation being just one simple example of such convexity.

\section{CONCLUSION}

In this paper, we provide a statistical description of Brazilian human capital dispersion, in time, across regions and states. Our analysis highlights several stylized facts.

First, there is in Brazil a strong reduction of educational inequalities as measured by Education Gini index. Despite the fact that this trend is shared by all regions and states, disparities remain important, reflecting educational geographical disparities and economic performance. A three parts picture of Brazil seems to emerge: Regions Norte and Nordeste with results showing a distinct improvement, but remaining weak. They suffer from unfavorable initial conditions inherited from the past. Regions and Sul correspond to regions most evenly distributed. Centro-Oeste exhibits high heterogeneity between states.

Second, we have shown that there is a strong diminution of educational inequalities as far as schooling achievement is concerned. In each state, the average years of schooling increased notably from 1,34 to 6,28 between year 1950 and year 2000 in Brazil.

Third, we have shown that there is a significant negative link between Education Gini and the average education length: higher education achievement leads to a more equitable distribution.

Finally, we have shown that Brazilian data are consistent with an Education Kuznets curve if we consider the education standard deviation, though evidence is yet somewhat weak.

However, there were a number of education reforms in Brazil over the period under analysis. Also, as long as education increases, the issue of quality of education gains importance. We obviously are not able to measure that point in our paper. It could be interesting to study more carefully the impact a such reforms on access to education and wages determination.

\footnotetext{
${ }^{32}$ Remember that standard deviation of schooling tends to follow an inverted- $U$ pattern in relation to mean schooling, with a peak when the mean is around seven years.
} 


\section{Bibliography}

Acemoglu, D. (1995). Reward structures and the allocation of talent. European Economic Review, 39(1):1733.

Aghion, P. \& Bolton, P. (1997). A theory of trickle-down growth and development. Review of Economic Studies, 64(2):151-72.

Alesina, A. \& Perotti, R. (1996). Income distribution, political instability, and investment. European Economic Review, 40(6):1203-1228.

Alesina, A. \& Rodrik, D. (1994). Distributive politics and economic growth. The Quarterly Journal of Economics, 109(2):465-90.

Atkinson, A. B. \& Bourguignon, F. (1998). Measurement of inequality. In Handbook of Income Distribution. North-Holland.

Barro, R. J. (1991). Economic growth in a cross section of countries. The Quarterly Journal of Economics, 106(2):407-43.

Barro, R. J. \& Lee, J.-W. (2001). International data on educational attainment: Updates and implications. Oxford Economic Papers, 53(3):541-63.

Barros, R. P. d., Henriques, R., \& Mendonça, R. (2002). Pelo fim das décadas perdidas: Educação e desenvolvimento sustentado no Brasil. TD 857, IPEA.

Barros, R. P. d. \& Mendonça, R. (1997). Investimentos em educação e desenvolvimento econômico. TD 525, IPEA.

Barros, R. P. d. \& Mendonça, R. (1998). O impacto de três inovações institucionais na educação brasileira. TD 556, IPEA.

Becker, G. S. \& Barro, R. J. (1988). A reformulation of the economic theory of fertility. The Quarterly Journal of Economics, 103(1):1-25.

Becker, G. S., Murphy, K. M., \& Tamura, R. (1990). Human capital, fertility, and economic growth. Journal of Political Economy, 98(5):S12-37.

Benabou, R. (1996). Inequality and growth. Macroeconomics Annual 11, NBER.

Benhabib, J. \& Rustichini, A. (1996). Social conflict, growth and income distribution. Journal of Economic Growth, 1(1).

Blom, A., Holm-Nielsen, L., \& D., V. (2001). Education, earning and inequality in brazil: 1982-98. implication for education policy. Working Paper 2686, World Bank Policy Research.

Bowman, K. S. (1997). Should the kuznets effect be relied on to induce equalizing growth: Evidence from post-1950 development. World Development, 25(1):127-143.

Ferreira, S. G. (2003). Mobilidade intergeracional de educação no Brasil. Pesquissa e Planejamento Econômico, 33(3).

Galor, O. \& Moav, O. (2002). Natural selection and the origin of economic growth. The Quarterly Journal of Economics, 117(4):1133-1191.

Galor, O. \& Zeira, J. (1993). Income distribution and macroeconomics. Review of Economic Studies, 60(1):35-52. 
Hussar, W. \& Sonnenberg, W. (2000). Trends in disparities in school district level expenditures per pupil. Technical Report 20, NCES.

Lam, D. (1999). Generating extreme inequality: Schooling, earnings and intergenerational transmission of human capital in South Africa and Brazil. Report 99-439, Population Studies Center.

Lam, D. \& Levison, D. (1991). Declining inequality in schooling in Brazil and its effects on inequality in earnings. Journal of Development Economics, 37(1-2):199-225.

Maas, J. \& Criel, C. (1982). Distribution of primary school enrollments in Eastern Africa. Technical Report WP 511, World Bank Staff.

Maddison, A. \& Associates (1992). The Political Economy of Poverty, Equality and Growth. Oxford University Press.

Psacharopoulos, G. \& Arriagada, A. M. (1986). The education attainment of the labor force: An international comparison. Technical Report EDT 38, World Bank Report.

Saint-Paul, G. \& Verdier, T. (1993). Education, democracy and growth. Journal of Development Economics, 42(2):399-407.

Thomas, V., Wang, Y., \& Fan, X. (2001). Measuring education inequality - Gini coefficients of education. Policy Research Working Paper Series 2525, The World Bank. 


\section{A. INDICATORS USED TO QUANTIFY EDUCATION}

Several indicators have been proposed to quantify alternative aspects of education. Some make use of flow variables such as the enrollment rate to different schooling levels (used mainly in relation with the primary and secondary education) as indicators of human accomplishment (e.g. Barro (1991)). These variables measure access flow to education and therefore do not take into account the schooling level achieved. These do not seem particularly appropriate measure to use in growth analysis where the stock of human capital is the main focus.

The difficulty with using stock measures such as achievement levels quantified by the average number of years of schooling, is due to missing. Thanks to Psacharopoulos and Arriagada (1986) and to Barro (1991), Barro and Lee (2001), robust international data about the average number of years of schooling are now available.

In recent years however, the emphasis has shifted toward quality rather than quantity indices of education. There are two main approaches:

i A first approach is concerned with measuring factors and resources used in the production of education. For instance the ration of professor to student, the average income earned by teachers, the number of libraries or books made available to students or public and private expenditures per student. But international comparisons using these measures are difficult because they crucially depend on countries' education system. Furthermore, high education budget does not necessarily imply quality of education of quality and by no means reveals anything on who accesses to education.

ii A second approach uses the international Test Score of Cognitive Performance. This test makes possible international comparisons of schooling achievements between students of the same age group. Subjects are common in sciences and mathematics and this test is run by the International Association for Evaluation of Educational Achievement (IEA) and by the International Assessment of Education Progress (IEAP). However, these recent efforts yet only cover a dozen of countries, mostly industrial, which limits their usefulness. Furthermore they are not fully time consistent.

Another kind of indicators is turning up. Indeed, in some studies indicators of disparities have been counted from various data; such as enrollment rates, financial rates, average expenditure per student or schooling achievement. For instance, Maas and Criel (1982) make use of the Gini Index on the enrollment rates for 16 East African countries. Hussar and Sonnenberg (2000) analyze the per student schooling expenditure disparities between US states and within states using among others coefficient of variation, Gini coefficient, Theil coefficient. Thomas et al. (2001) consider a Gini index on schooling achievement of population aged over fifteen between 1960 and 1990 for 85 countries.

\section{B. DESIRABLE PROPERTIES OF THE INEQUALITY INDICES}

The idea of inequality refers to several domains: income, health, education... An inequality index is a scalar summary of the dispersion of the distribution and as such necessarily disregards a lot of important pieces of data about the distribution.

There are many ways of measuring inequality, all of which have some intuitive or mathematical appeal. However, many apparently sensible measures behave in perverse fashions. For example, the variance, which must be one of the simplest measures of inequality, is not independent of the income scale: ${ }^{33}$ simply doubling all incomes would register a quadrupling of the estimate of income inequality. We list several properties with the axiomatic approach that a perfect inequality index would have to

${ }^{33}$ See Atkinson and Bourguignon (1998). 
satisfy. Of course, such a perfect indicator does not exist and depending on the data at your disposal, on the analyses framework, we will privilege one indicator rather than another one.

i Pigou-Dalton Transfer Condition (PDT): transfers of benefits from the "rich" to the "poor" do not have to reverse the ranking. Most measures in the literature, including the Generalized Entropy class, the Atkinson class and the Gini coefficient, satisfy this principle, with the main exception of the logarithmic variance and the variance of logarithms.

ii Translation Invariance (TI): the inequality is unchanged when all individual benefits increase by the same amount.

iii Scale Invariance (SI): the inequality is unchanged when all individual benefits increase in the same proportion. Again most standard measures pass this test except the variance since $\operatorname{var}(\lambda y)=$ $\lambda^{2} \operatorname{var}(y)$.

iv Subgroup Consistency (SC): when only a subgroup of agents is affected by a change in their benefits, the overall inequality moves in the same direction as this subgroup inequality.

v Diminishing Transfers (DT): a transfer from rich to poor decreases inequality more when it is made at the lower tail of the distribution than when it is made at the upper tail.

Generalized entropy: $\frac{1}{c(c-1)}\left[\sum_{i} p_{i}\left(\frac{x_{i}}{\bar{x}}\right)^{c}-1\right]$ where $c$ is a given parameter. For $c<2$, it satisfies all above conditions, except TI. Note that if $c=0$, the formula becomes: $\left[\sum_{i} p_{i} \ln \left(\frac{x_{i}}{\bar{x}}\right)\right]$ and if $c=1$, it becomes the Theil Index: $\left[\sum_{i} \frac{p_{i} x_{i}}{\bar{x}} \ln \left(\frac{x_{i}}{\bar{x}}\right)\right]$. Notice that for all $c<1$, it is ordinal equivalent to the Kolm-Atkinson Index with $\varepsilon=1-c$.

\section{TABLES}


Table 1 - Regression: Earnings Function

\begin{tabular}{|c|c|c|c|c|c|c|}
\hline & Brazil & Norte & Nordeste & Sudeste & Sul & $\begin{array}{l}\text { Centro- } \\
\text { Oeste }\end{array}$ \\
\hline Constant & $\begin{array}{l}5,452 \\
(11,12)\end{array}$ & $\begin{array}{l}5,726 \\
(7,81)\end{array}$ & $\begin{array}{l}6,447 \\
(13,01)\end{array}$ & $5,093(8,1)$ & $\begin{array}{l}5,482 \\
(6,89)\end{array}$ & $\begin{array}{l}5,239 \\
(9,38)\end{array}$ \\
\hline $\mathrm{e} 0$ & $0,215(3,75)$ & $\begin{array}{l}0,052 \\
(0,07) \\
\end{array}$ & $0,03(3,62)$ & $\begin{array}{l}0,245 \\
(3,06) \\
\end{array}$ & $\begin{array}{l}0,41 \\
(2,15) \\
\end{array}$ & $\begin{array}{l}0,219 \\
(3,17) \\
\end{array}$ \\
\hline e1 & $\begin{array}{l}-0,578 \\
(-3,91)\end{array}$ & $-0,29(-1,8)$ & $\begin{array}{l}-0,173 \\
(-3,94)\end{array}$ & $\begin{array}{l}-0,479 \\
(-3,02)\end{array}$ & $\begin{array}{l}-0,577 \quad(- \\
2,13)\end{array}$ & $-0,98(-3,3)$ \\
\hline e3 & $0,949(3,49)$ & $\begin{array}{l}0,795 \\
(1,45)\end{array}$ & $\begin{array}{l}0,564 \\
(3,64)\end{array}$ & $\begin{array}{l}0,477 \\
(2,88)\end{array}$ & $\begin{array}{l}0,505 \\
(1,86)\end{array}$ & $\begin{array}{l}1,459 \\
(2,93)\end{array}$ \\
\hline e4 & $\begin{array}{l}-0,526 \\
(-3,49)\end{array}$ & $\begin{array}{l}-0,467 \\
(-1,49)\end{array}$ & $\begin{array}{l}-0,262 \\
(-3,75)\end{array}$ & $\begin{array}{l}-0,2 \\
2,86)\end{array}$ & $\begin{array}{l}-0,254 \quad(- \\
1,78)\end{array}$ & $\begin{array}{l}-0,67 \\
(-2,84)\end{array}$ \\
\hline e5 & $0,578(4,62)$ & $\begin{array}{l}1,179 \\
(2,47) \\
\end{array}$ & $\begin{array}{l}0,3 \\
(4,63) \\
\end{array}$ & $\begin{array}{l}0,125 \\
(3,36) \\
\end{array}$ & $\begin{array}{l}0,3 \\
(2,35) \\
\end{array}$ & $\begin{array}{l}0,743 \\
(4,12) \\
\end{array}$ \\
\hline Adj $R^{2}$ & 0,8784 & 0,7054 & 0,8833 & 0,8241 & 0,699 & 0,8551 \\
\hline
\end{tabular}

e0: No School; e1: Between 1 and 3 years; e3: Between 8 and 10 years; e4: Between 11 and 14 years; e5: More than 15 years 
Table 2 - Trend of Education Gini of Brazilians 5 years and over - Region - State (1950-2000)

\begin{tabular}{|c|c|c|c|c|c|c|c|}
\hline Regions & States & 1950 & 1960 & 1970 & 1980 & 1990 & 2000 \\
\hline Brazil & & 0,7868 & 0,6246 & 0,6485 & 0,5830 & 0,5307 & 0,4031 \\
\hline \multirow{7}{*}{ Norte } & Acre & 0,8807 & 0,7743 & 0,7929 & 0,7442 & 0,6510 & 0,4970 \\
\hline & Amapa & 0,8294 & 0,6696 & 0,6344 & 0,5874 & 0,5178 & 0,4279 \\
\hline & Rondonia & 0,7788 & 0,6656 & 0,7052 & 0,6344 & 0,5385 & 0,4189 \\
\hline & Roraima & 0,8355 & 0,7268 & 0,6235 & 0,6077 & 0,5282 & 0,3779 \\
\hline & Amazonas & 0,8506 & 0,7020 & 0,7191 & 0,6541 & 0,5669 & 0,4353 \\
\hline & Para & 0,7661 & 0,6367 & 0,6571 & 0,6347 & 0,5664 & 0,4403 \\
\hline & NORTE & 0,7989 & 0,6659 & 0,6823 & 0,6439 & 0,5662 & 0,4366 \\
\hline \multirow{6}{*}{ Centro-Oeste } & Mato-Grosso do Sul & & & & 0,5874 & 0,5036 & 0,4069 \\
\hline & Mato-Grosso & 0,7726 & 0,6302 & 0,6758 & 0,6252 & 0,5246 & 0,4109 \\
\hline & Goias & 0,9115 & 0,7031 & 0,7035 & 0,6164 & 0,5126 & 0,3829 \\
\hline & Tocantins & & & & & 0,6352 & 0,4494 \\
\hline & Distrito Federal & 0,5275 & 0,5432 & 0,5510 & 0,4789 & 0,4065 & 0,3142 \\
\hline & CENTRO-OESTE & 0,6714 & 0,6738 & 0,6851 & 0,5969 & 0,5023 & 0,3847 \\
\hline \multirow{5}{*}{ Sudeste } & Minas Gerais & 0,7988 & 0,6366 & 0,6448 & 0,5577 & 0,5131 & 0,3921 \\
\hline & Espirito Santo & 0,8044 & 0,6387 & 0,6493 & 0,5556 & 0,5056 & 0,3900 \\
\hline & Rio de Janeiro & 0,7584 & 0,4847 & 0,5155 & 0,4799 & 0,4176 & 0,3427 \\
\hline & Sao Paulo & 0,6741 & 0,5102 & 0,5361 & 0,4927 & 0,4323 & 0,3418 \\
\hline & SUDESTE & 0,7391 & 0,5496 & 0,5707 & 0,5111 & 0,4558 & 0,3585 \\
\hline \multirow{4}{*}{ Sul } & Parana & 0,7831 & 0,6276 & 0,6478 & 0,5493 & 0,4842 & 0,3717 \\
\hline & Santa Catarina & 0,6525 & 0,5434 & 0,5124 & 0,4526 & 0,4009 & 0,3417 \\
\hline & Rio Grande do Sul & 0,6586 & 0,5081 & 0,5097 & 0,4557 & 0,4134 & 0,3410 \\
\hline & SUL & 0,6916 & 0,5617 & 0,5705 & 0,4931 & 0,4383 & 0,3526 \\
\hline \multirow{10}{*}{ Nordeste } & Maranhao & 0,8786 & 0,7789 & 0,7991 & 0,7544 & 0,6949 & 0,5116 \\
\hline & Piaui & 0,9253 & 0,8107 & 0,8364 & 0,7597 & 0,7209 & 0,5182 \\
\hline & Ceara & 0,9180 & 0,7533 & 0,8144 & 0,7306 & 0,6936 & 0,4650 \\
\hline & Rio Grande do Norte & 0,8921 & 0,7267 & 0,7640 & 0,6874 & 0,6652 & 0,4648 \\
\hline & Paraiba & 0,9128 & 0,7687 & 0,8010 & 0,7365 & 0,7140 & 0,4998 \\
\hline & Pernambuco & 0,9009 & 0,7319 & 0,7551 & 0,6874 & 0,6362 & 0,4630 \\
\hline & Alagoas & 0,9199 & 0,7902 & 0,8243 & 0,7713 & 0,7203 & 0,5148 \\
\hline & Sergipe & 0,8803 & 0,7471 & 0,7917 & 0,7261 & 0,6597 & 0,4761 \\
\hline & Bahia & 0,8873 & 0,7500 & 0,7884 & 0,7887 & 0,6743 & 0,4831 \\
\hline & NORDESTE & 0,9018 & 0,7597 & 0,7930 & 0,7302 & 0,6805 & 0,4856 \\
\hline Maximum State & & 0,9253 & 0,8107 & 0,8364 & 0,7887 & 0,7209 & 0,5182 \\
\hline Etat State & & Piaui & Piaui & Piaui & Bahia & Piaui & Piaui \\
\hline Max Region & & 0,9018 & 0,7597 & 0,7930 & 0,7302 & 0,6805 & 0,4856 \\
\hline Region Max & & Nordeste & Nordeste & Nordeste & Nordeste & \multicolumn{2}{|c|}{ NordesteNordeste } \\
\hline Min State & & 0,5275 & 0,4847 & 0,5097 & 0,4526 & 0,4009 & 0,3142 \\
\hline State Min* & & DF & $\mathrm{RJ}$ & RGS & SC & DF & DF \\
\hline Min Region & & 0,6714 & 0,5496 & 0,5705 & 0,4931 & 0,4383 & 0,3526 \\
\hline Region Min & & $\mathrm{CO}$ & Sudeste & Sul & Sul & Sul & Sul \\
\hline
\end{tabular}

${ }^{*}$ DF lies for Distrito Federal, CO for region Centro-Oeste, RJ for Rio de Janeiro, RGS for Rio Grande do Sul and SC for Santa Catarina. Data from IBGE. 
Table 3 - Trend of Education Gini with No Schooling of Brazilians 5 year and over (1950-2000)

\begin{tabular}{|c|c|c|c|c|c|c|c|}
\hline Regions & States & 1950 & 1960 & 1970 & 1980 & 1990 & 2000 \\
\hline Brazil & Total - Brésil & 0,3531 & 0,3222 & 0,3772 & 0,3571 & 0,3606 & 0,3302 \\
\hline \multirow{7}{*}{ Norte } & Acre & 0,3732 & 0,3150 & 0,3762 & 0,3676 & 0,3749 & 0,3573 \\
\hline & Amapa & 0,4023 & 0,3371 & 0,3596 & 0,3518 & 0,3391 & 0,3350 \\
\hline & Rondonia & 0,3767 & 0,2992 & 0,3687 & 0,3454 & 0,3534 & 0,3441 \\
\hline & Roraima & 0,3789 & 0,3392 & 0,3427 & 0,3596 & 0,3352 & 0,2993 \\
\hline & Amazonas & 0,3907 & 0,3407 & 0,4062 & 0,3749 & 0,3529 & 0,3231 \\
\hline & Para & 0,3637 & 0,3234 & 0,3883 & 0,3726 & 0,3772 & 0,3523 \\
\hline & NORTE & 0,3718 & 0,3279 & 0,3909 & 0,3710 & 0,3688 & 0,3426 \\
\hline \multirow{4}{*}{ Centro-Oeste } & Mato Grosso & 0,3728 & 0,3370 & 0,3893 & 0,3596 & 0,3585 & 0,3292 \\
\hline & Goias & 0,3971 & 0,3547 & 0,4041 & 0,3647 & 0,3546 & 0,3200 \\
\hline & Distrito Federal & 0,3051 & 0,3427 & 0,3752 & 0,3532 & 0,3195 & 0,2834 \\
\hline & CENTRO-OESTE & 0,3297 & 0,3529 & 0,4074 & 0,3701 & 0,3582 & 0,3210 \\
\hline \multirow{4}{*}{ Sudeste } & Minas Gerais & 0,3518 & 0,3159 & 0,3697 & 0,3483 & 0,3557 & 0,3275 \\
\hline & Espirito Santo & 0,3791 & 0,3186 & 0,3786 & 0,3501 & 0,3501 & 0,3242 \\
\hline & Rio de Janiero & 0,3502 & 0,2988 & 0,3548 & 0,3470 & 0,3319 & 0,3008 \\
\hline & São Paulo & 0,3286 & 0,2957 & 0,3560 & 0,3486 & 0,3458 & 0,2986 \\
\hline & SUDESTE & 0,3443 & 0,3093 & 0,3658 & 0,3512 & 0,3490 & 0,3093 \\
\hline \multirow{4}{*}{ Sul } & Parana & 0,3631 & 0,3270 & 0,3725 & 0,3539 & 0,3618 & 0,3169 \\
\hline & Santa Catarina & 0,2893 & 0,3061 & 0,3233 & 0,3131 & 0,3291 & 0,3097 \\
\hline & Rio Grande do Sul & 0,3191 & 0,2957 & 0,3331 & 0,3229 & 0,3344 & 0,3054 \\
\hline & SUL & 0,3232 & 0,3121 & 0,3503 & 0,3334 & 0,3436 & 0,3108 \\
\hline \multirow{10}{*}{ Nordeste } & Maranhão & 0,3378 & 0,3157 & 0,3860 & 0,3824 & 0,3910 & 0,3643 \\
\hline & Piaui & 0,3831 & 0,3547 & 0,4130 & 0,3877 & 0,3988 & 0,3723 \\
\hline & Ceara & 0,4043 & 0,3525 & 0,4309 & 0,3904 & 0,3987 & 0,3555 \\
\hline & Rio Grande do Norte & 0,3643 & 0,3197 & 0,3775 & 0,3680 & 0,3918 & 0,3585 \\
\hline & Paraiba & 0,3749 & 0,3382 & 0,4110 & 0,3881 & 0,4044 & 0,3691 \\
\hline & Pernambuco & 0,3760 & 0,3407 & 0,3955 & 0,3809 & 0,3746 & 0,3574 \\
\hline & Alagoas & 0,3891 & 0,3448 & 0,4162 & 0,3897 & 0,3913 & 0,3752 \\
\hline & Sergipe & 0,3964 & 0,3535 & 0,4296 & 0,3852 & 0,3861 & 0,3717 \\
\hline & Bahia & 0,3714 & 0,3402 & 0,4114 & 0,3877 & 0,3943 & 0,3629 \\
\hline & NORDESTE & 0,3808 & 0,3430 & 0,4097 & 0,3860 & 0,3923 & 0,3647 \\
\hline Max State & & 0,4043 & 0,3547 & 0,4309 & 0,3904 & 0,4044 & 0,3752 \\
\hline State Max & & Ceara & Goias & Ceara & Ceara & Paraiba & Alagoas \\
\hline Max Region & & 0,3808 & 0,3529 & 0,4097 & 0,3860 & 0,3923 & 0,3647 \\
\hline Region Max & & Nordeste & $\mathrm{CO}$ & Nordeste & Nordeste & \multicolumn{2}{|c|}{ NordesteNordeste } \\
\hline Min State & & 0,2893 & 0,2957 & 0,3233 & 0,3131 & 0,3195 & 0,2834 \\
\hline State Min & & SC & RS & SC & SC & DF & $\mathrm{DF}$ \\
\hline Min Region & & 0,3232 & 0,3093 & 0,3503 & 0,3334 & 0,3436 & 0,3093 \\
\hline Region Min & & Sul & Sudeste & Sul & Sul & Sul & Sudeste \\
\hline
\end{tabular}

SC lies for Santa Catarina, RS for Rio Grande do Sul, DF for Distrito Federal and CO for Region Centro-Oeste. Data from IBGE. 
Table 4 - Trend of No Schooling of Brazilian 5 years and over - Region - State (1950-2000)

\begin{tabular}{|c|c|c|c|c|c|c|c|}
\hline Regions & States & 1950 & 1960 & 1970 & 1980 & 1990 & 2000 \\
\hline Brazil & & 0,6705 & 0,5103 & 0,4357 & 0,3514 & 0,2661 & 0,1089 \\
\hline \multirow{7}{*}{ Norte } & Acre & 0,8097 & 0,7086 & 0,6680 & 0,5955 & 0,4416 & 0,2174 \\
\hline & Amapa & 0,7146 & 0,5450 & 0,4291 & 0,3634 & 0,2704 & 0,1398 \\
\hline & Rondonia & 0,6452 & 0,5493 & 0,5331 & 0,4414 & 0,2862 & 0,1141 \\
\hline & Roraima & 0,7351 & 0,6229 & 0,4272 & 0,3873 & 0,2904 & 0,1123 \\
\hline & Amazonas & 0,7547 & 0,6035 & 0,5269 & 0,4467 & 0,3307 & 0,1657 \\
\hline & Para & 0,6325 & 0,5022 & 0,4394 & 0,4178 & 0,3038 & 0,1359 \\
\hline & NORTE & 0,6800 & 0,5463 & 0,4784 & 0,4338 & 0,3128 & 0,1431 \\
\hline \multirow{6}{*}{ Centro-Oeste } & Mato-Grosso do Sul & & & & 0,3564 & 0,2236 & 0,1251 \\
\hline & Mato-Grosso & 0,6374 & 0,4782 & 0,4692 & 0,4144 & 0,2621 & 0,1115 \\
\hline & Goias & 0,8532 & 0,5868 & 0,5024 & 0,3961 & 0,2448 & 0,0926 \\
\hline & Tocantins & & & & & 0,4162 & 0,1610 \\
\hline & Distrito Federal & 0,3201 & 0,3608 & 0,2815 & 0,1942 & 0,1278 & 0,0430 \\
\hline & CENTRO-OESTE & 0,5097 & 0,5429 & 0,4686 & 0,3601 & 0,2245 & 0,0938 \\
\hline \multirow{4}{*}{ Sudeste } & Minas Gerais & 0,6896 & 0,5287 & 0,4365 & 0,3214 & 0,2443 & 0,0961 \\
\hline & Espirito Santo & 0,6850 & 0,5316 & 0,4356 & 0,3162 & 0,2393 & 0,0973 \\
\hline & Rio de Janeiro & 0,6282 & 0,3127 & 0,2490 & 0,2035 & 0,1283 & 0,0599 \\
\hline & Sao Paulo & 0,5145 & 0,3645 & 0,2796 & 0,2212 & 0,1322 & 0,0615 \\
\hline & SUDESTE & 0,6021 & 0,4098 & 0,3230 & 0,2465 & 0,1640 & 0,0713 \\
\hline \multirow{4}{*}{ Sul } & Parana & 0,6594 & 0,4985 & 0,4388 & 0,3025 & 0,1918 & 0,0801 \\
\hline & Santa Catarina & 0,5110 & 0,3591 & 0,2794 & 0,2031 & 0,1069 & 0,0463 \\
\hline & Rio Grande do Sul & 0,4985 & 0,3254 & 0,2648 & 0,1960 & 0,1187 & 0,0506 \\
\hline & SUL & 0,5443 & 0,3934 & 0,3389 & 0,2396 & 0,1442 & 0,0607 \\
\hline \multirow{10}{*}{ Nordeste } & Maranhao & 0,8166 & 0,7170 & 0,6728 & 0,6024 & 0,4991 & 0,2317 \\
\hline & Piaui & 0,8789 & 0,7778 & 0,7213 & 0,6075 & 0,5358 & 0,2325 \\
\hline & Ceara & 0,8624 & 0,7141 & 0,6738 & 0,5580 & 0,4903 & 0,1699 \\
\hline & Rio Grande do Norte & 0,8303 & 0,6467 & 0,6208 & 0,5054 & 0,4495 & 0,1657 \\
\hline & Paraiba & 0,8717 & 0,6985 & 0,6622 & 0,5694 & 0,5198 & 0,2072 \\
\hline & Pernambuco & 0,8412 & 0,6746 & 0,5949 & 0,4951 & 0,4184 & 0,1643 \\
\hline & Alagoas & 0,8689 & 0,7637 & 0,6991 & 0,6253 & 0,5406 & 0,2235 \\
\hline & Sergipe & 0,8017 & 0,6619 & 0,6349 & 0,5545 & 0,4457 & 0,1662 \\
\hline & Bahia & 0,8206 & 0,6857 & 0,7085 & 0,5732 & 0,4622 & 0,1887 \\
\hline & NORDESTE & 0,8413 & 0,7052 & 0,6493 & 0,5606 & 0,4742 & 0,1904 \\
\hline Max State & & 0,8789 & 0,7778 & 0,7213 & 0,6253 & 0,5406 & 0,2325 \\
\hline State Max & & Piaui & Piaui & Piaui & Alagoas & Alagoas & Piaui \\
\hline Max Region & & 0,8413 & 0,7052 & 0,6493 & 0,5606 & 0,4742 & 0,1904 \\
\hline Region Max & & Nordeste & Nordeste & Nordeste & Nordeste & \multicolumn{2}{|c|}{ NordesteNordeste } \\
\hline Min State & & 0,3201 & 0,3127 & 0,2490 & 0,1942 & 0,1069 & 0,0430 \\
\hline State Min & & DF & $\mathrm{RJ}$ & $\mathrm{RJ}$ & DF & SC & DF \\
\hline Min Region & & 0,5097 & 0,3934 & 0,3230 & 0,2396 & 0,1442 & 0,0607 \\
\hline Region Min & & $\mathrm{CO}$ & Sul & Sudeste & Sul & Sul & Sul \\
\hline
\end{tabular}

DF lies for Distrito Federal, CO for region Centro-Oeste, RJ for Rio de Janeiro and SC for Santa Catarina. Data from IBGE. 
Table 5 - Trend of Average Number of Years of Schooling of Brazilians 5 years and over - Region - State (1950-2000)

\begin{tabular}{|c|c|c|c|c|c|c|c|}
\hline Regions & States & 1950 & 1960 & 1970 & 1980 & 1990 & 2000 \\
\hline Brazil & & 1,3461 & 1,8011 & 2,3902 & 3,2366 & 4,3623 & 6,2779 \\
\hline \multirow{7}{*}{ Norte } & Acre & 0,5550 & 0,7904 & 1,0904 & 1,7887 & 3,1211 & 4,8404 \\
\hline & Amapa & 0,8475 & 1,4604 & 2,2767 & 3,0556 & 4,3364 & 5,5453 \\
\hline & Rondonia & 1,1272 & 1,5192 & 1,8024 & 2,1875 & 3,6778 & 5,6272 \\
\hline & Roraima & 0,9506 & 1,2639 & 2,2492 & 2,8624 & 4,2721 & 6,1357 \\
\hline & Amazonas & 0,8334 & 1,2478 & 1,7546 & 2,5403 & 3,8869 & 5,5645 \\
\hline & Para & 1,1696 & 1,5397 & 1,9940 & 2,5448 & 3,4655 & 5,3557 \\
\hline & NORTE & 1,0298 & 1,4082 & 1,8833 & 2,4945 & 3,6182 & 5,4505 \\
\hline \multirow{6}{*}{ Centro-Oeste } & Mato-Grosso do Sul & & & & 2,8998 & 4,5086 & 5,7983 \\
\hline & Mato-Grosso & 1,2725 & 1,6493 & 1,7882 & 2,5383 & 4,0478 & 5,8802 \\
\hline & Goias & 0,5082 & 1,1255 & 1,6626 & 2,7281 & 4,4219 & 6,4421 \\
\hline & Tocantins & & & & & 2,6515 & 5,2013 \\
\hline & Distrito Federal & 3,9786 & 2,7186 & 3,8934 & 5,1189 & 7,0641 & 8,3872 \\
\hline & CENTRO-OESTE & 2,6666 & 1,3621 & 1,9378 & 3,1041 & 4,8086 & 6,5575 \\
\hline \multirow{4}{*}{ Sudeste } & Minas Gerais & 1,1428 & 1,5814 & 2,1991 & 3,1814 & 4,0884 & 6,1413 \\
\hline & Espirito Santo & 0,9796 & 1,4908 & 2,2134 & 3,3736 & 4,3855 & 5,9597 \\
\hline & Rio de Janeiro & 1,5399 & 3,2240 & 3,9264 & 4,6683 & 6,1743 & 7,5609 \\
\hline & Sao Paulo & 2,1922 & 2,5673 & 3,3584 & 4,2152 & 5,5420 & 7,4686 \\
\hline & SUDESTE & 1,6609 & 2,3725 & 3,1160 & 4,0189 & 5,2580 & 7,0954 \\
\hline \multirow{4}{*}{ Sul } & Parana & 1,2469 & 1,6340 & 2,0466 & 3,1983 & 4,5540 & 6,7343 \\
\hline & Santa Catarina & 1,7530 & 2,0028 & 2,6597 & 3,7980 & 5,0425 & 6,8176 \\
\hline & Rio Grande do Sul & 1,8761 & 2,5988 & 3,2517 & 4,1286 & 5,2505 & 6,9348 \\
\hline & SUL & 1,6828 & 2,1475 & 2,6527 & 3,6973 & 4,9419 & 6,8356 \\
\hline \multirow{10}{*}{ Nordeste } & Maranhao & 0,5613 & 0,7567 & 1,0460 & 1,6153 & 2,4478 & 4,1801 \\
\hline & Piaui & 0,4614 & 0,6723 & 0,9604 & 1,6511 & 2,4111 & 3,9125 \\
\hline & Ceara & 0,4824 & 0,8699 & 1,2298 & 1,9426 & 2,7644 & 4,9521 \\
\hline & Rio Grande do Norte & 0,5671 & 1,1069 & 1,4071 & 2,2328 & 3,1152 & 4,9736 \\
\hline & Paraiba & 0,4439 & 0,9113 & 1,2079 & 1,9488 & 2,7007 & 4,4752 \\
\hline & Pernambuco & 0,6518 & 1,1432 & 1,6719 & 2,4414 & 3,4035 & 5,5676 \\
\hline & Alagoas & 0,4725 & 0,7433 & 1,0895 & 1,6959 & 2,5633 & 4,5058 \\
\hline & Sergipe & 0,5975 & 0,9147 & 1,2369 & 1,9910 & 3,0846 & 5,0933 \\
\hline & Bahia & 0,6176 & 0,9884 & 1,3293 & 1,9081 & 2,8080 & 4,8241 \\
\hline & NORDESTE & 0,5614 & 0,9179 & 1,3030 & 1,9720 & 2,8361 & 4,8156 \\
\hline Max State & & 3,9786 & 3,2240 & 3,9264 & 5,1189 & 7,0641 & 8,3872 \\
\hline State Max & & DF & $\mathrm{RJ}$ & RJ & DF & $\mathrm{DF}$ & $\mathrm{DF}$ \\
\hline Max Region & & 2,6666 & 2,3725 & 3,1160 & 4,0189 & 5,2580 & 7,0954 \\
\hline Region Max & & $\mathrm{CO}$ & Sudeste & Sudeste & Sudeste & Sudeste & Sudeste \\
\hline Min State & & 0,4439 & 0,6723 & 0,9604 & 1,6153 & 2,4111 & 3,9125 \\
\hline State Min & & Paraiba & Piaui & Piaui & Maranhão & Piaui & Piaui \\
\hline Min Region & & 0,5614 & 0,9179 & 1,3030 & 1,9720 & 2,8361 & 4,8156 \\
\hline Region Min & & Nordeste & Nordeste & Nordeste & Nordeste & Nordeste & Nordeste \\
\hline
\end{tabular}

DF lies for Distrito Federal, CO for region Centro-Oeste and RJ for Rio de Janeiro. Data from IBGE. 
Table 6 - Trend of Education Standard Deviation of Brazilian 5 years and over - Region - State (19502000)

\begin{tabular}{|c|c|c|c|c|c|c|c|}
\hline Regions & States & 1950 & 1960 & 1970 & 1980 & 1990 & 2000 \\
\hline Brazil & & 2,5524 & 2,6595 & 3,1703 & 3,6296 & 4,3242 & 4,5703 \\
\hline \multirow{7}{*}{ Norte } & Acre & 1,5320 & 1,6251 & 2,1312 & 2,9432 & 4,0028 & 4,4260 \\
\hline & Amapa & 1,9285 & 2,2728 & 2,8703 & 3,4061 & 4,1005 & 4,3061 \\
\hline & Rondonia & 2,1263 & 2,2050 & 2,7084 & 2,7937 & 3,7337 & 4,2942 \\
\hline & Roraima & 2,1325 & 2,1956 & 2,7864 & 3,3637 & 4,1143 & 4,1680 \\
\hline & Amazonas & 1,9967 & 2,1765 & 2,7754 & 3,3248 & 4,0946 & 4,3538 \\
\hline & Para & 2,1300 & 2,2485 & 2,7365 & 3,2232 & 3,7696 & 4,3074 \\
\hline & NORTE & 2,0669 & 2,2039 & 2,7292 & 3,2154 & 3,8802 & 4,3217 \\
\hline \multirow{5}{*}{ Centro-Oeste } & Mato-Grosso do Sul & & & & 3,3150 & 4,2041 & 4,2809 \\
\hline & Mato-Grosso & 2,3291 & 2,3091 & 2,5855 & 3,1584 & 3,9744 & 4,4099 \\
\hline & Goias & 1,6311 & 1,9922 & 2,5874 & 3,3072 & 4,1862 & 4,4532 \\
\hline & Tocantins & & & & & 3,3756 & 4,2781 \\
\hline & Distrito Federal & 4,0037 & 3,4062 & 4,0317 & 4,4184 & 5,0470 & 4,7055 \\
\hline & CENTRO-OESTE & 3,6789 & 2,2154 & 2,8559 & 3,5922 & 4,4282 & 4,5470 \\
\hline \multirow{4}{*}{ Sudeste } & Minas Gerais & 2,2530 & 2,3920 & 2,9478 & 3,4257 & 4,0012 & 4,3916 \\
\hline & Espirito Santo & 2,0161 & 2,2975 & 2,9619 & 3,5602 & 4,1299 & 4,2194 \\
\hline & Rio de Janeiro & 2,6865 & 3,4576 & 3,7977 & 4,1013 & 4,6236 & 4,6353 \\
\hline & Sao Paulo & 3,0947 & 3,0352 & 3,5014 & 3,8748 & 4,4031 & 4,5867 \\
\hline & SUDESTE & 2,7547 & 3,0035 & 3,4721 & 3,8462 & 4,4086 & 4,5772 \\
\hline \multirow{4}{*}{ Sul } & Parana & 2,3570 & 2,3989 & 2,7723 & 3,3863 & 4,1346 & 4,5061 \\
\hline & Santa Catarina & 2,2985 & 2,1503 & 2,6744 & 3,2481 & 3,8387 & 4,2454 \\
\hline & Rio Grande do Sul & 2,5508 & 2,6913 & 3,1643 & 3,5475 & 4,0704 & 4,3225 \\
\hline & SUL & 2,4666 & 2,5373 & 2,9758 & 3,4545 & 4,0610 & 4,3768 \\
\hline \multirow{10}{*}{ Nordeste } & Maranhao & 1,5090 & 1,5841 & 2,0888 & 2,7505 & 3,5398 & 4,0139 \\
\hline & Piaui & 1,5770 & 1,7120 & 2,1637 & 2,8399 & 3,7115 & 3,8929 \\
\hline & Ceara & 1,6204 & 1,9655 & 2,5561 & 3,0950 & 3,9519 & 4,2460 \\
\hline & Rio Grande do Norte & 1,6339 & 2,0062 & 2,5022 & 3,1906 & 4,1565 & 4,2723 \\
\hline & Paraiba & 1,4885 & 1,8731 & 2,4118 & 3,1646 & 4,0824 & 4,2182 \\
\hline & Pernambuco & 1,9353 & 2,2871 & 2,8740 & 3,4618 & 4,2383 & 4,7089 \\
\hline & Alagoas & 1,5918 & 1,8302 & 2,3623 & 3,0163 & 3,9152 & 4,3669 \\
\hline & Sergipe & 1,6413 & 1,8413 & 2,4409 & 3,1243 & 4,0521 & 4,4858 \\
\hline & Bahia & 1,7253 & 2,0169 & 2,5465 & 3,0992 & 3,8473 & 4,3022 \\
\hline & NORDESTE & 1,6912 & 1,9677 & 2,5292 & 3,1326 & 3,9377 & 4,3371 \\
\hline Max State & & 4,0037 & 3,4576 & 4,0317 & 4,4184 & 5,0470 & 4,7089 \\
\hline State Max & & $\mathrm{DF}$ & RJ & $\mathrm{DF}$ & $\mathrm{DF}$ & DF & DF \\
\hline Max Region & & 3,6789 & 3,0035 & 3,4721 & 3,8462 & 4,4282 & 4,5772 \\
\hline Region Max & & $\mathrm{CO}$ & Sudeste & Sudeste & Sudeste & $\mathrm{CO}$ & $\mathrm{CO}$ \\
\hline Min State & & 1,4885 & 1,5841 & 2,0888 & 2,7505 & 3,3756 & 3,8929 \\
\hline State Min & & Paraiba & Maranhão & Maranhão & Maranhão & Tocantin & Piaui \\
\hline Min Region & & 1,6912 & 1,9677 & 2,5292 & 3,1326 & 3,8802 & 4,3217 \\
\hline Region Min & & Nordeste & Nordeste & Nordeste & Nordeste & Norte & Norte \\
\hline
\end{tabular}

DF lies for Distrito Federal, CO for region Centro-Oeste and RJ for Rio de Janeiro. Data from IBGE. 


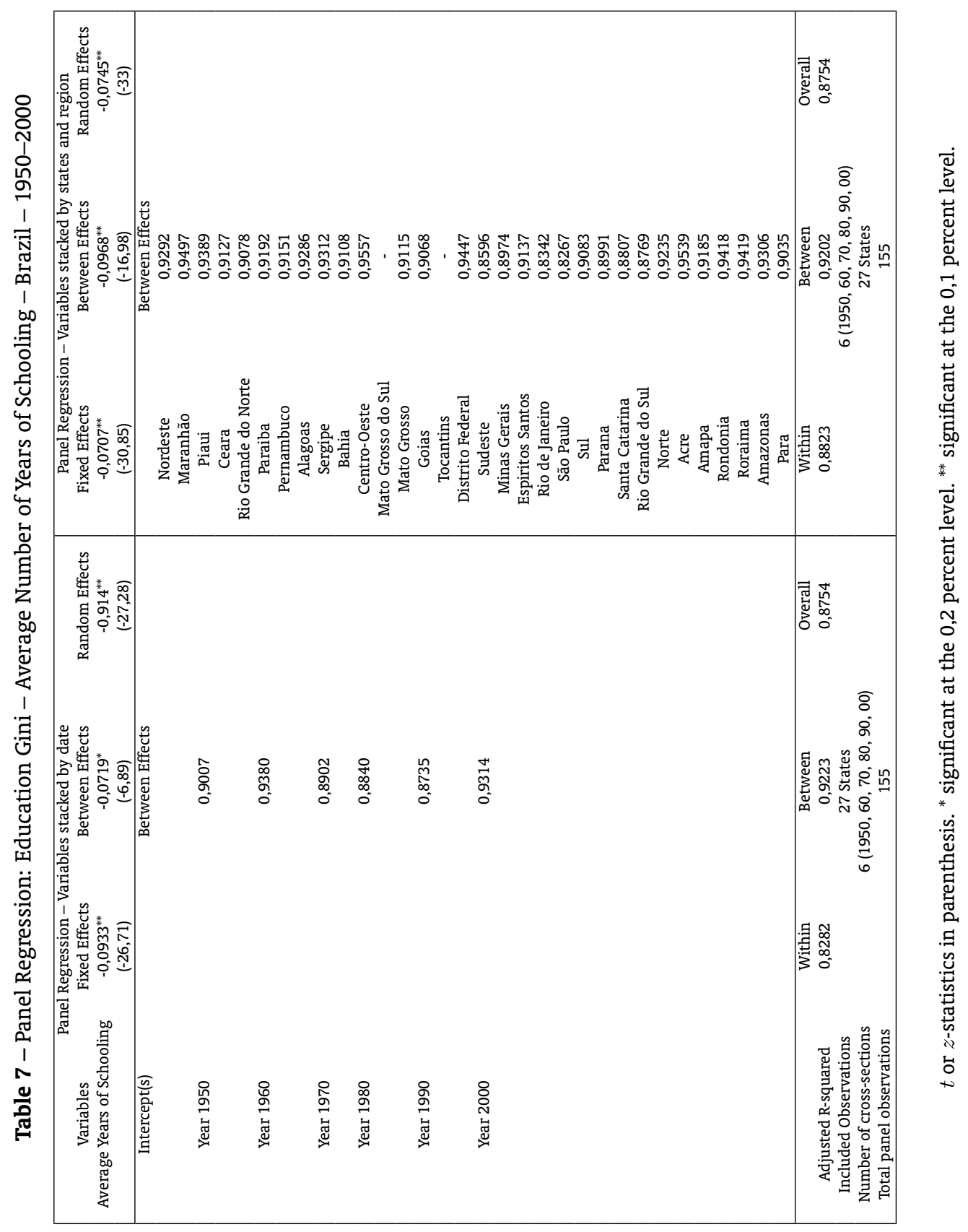


Table 8 - Log and Parabolic Regression: Education Standard Deviation - Average Number of Years of Schooling - Brazil - 1950-2000

\begin{tabular}{|c|c|c|c|c|c|c|c|}
\hline \multicolumn{4}{|c|}{ Parabolic-fit } & \multicolumn{4}{|c|}{ Logaritmic-fit } \\
\hline \multirow[t]{3}{*}{ R-sq } & \multicolumn{3}{|c|}{ Random 0,8149 Observations 155} & \multirow[t]{3}{*}{ R-sq } & \multicolumn{3}{|c|}{ Random 0,9229 Observations 155} \\
\hline & Within & 0,8896 & Groups 27 & & Within & 0,9634 & Groups 27 \\
\hline & \multicolumn{3}{|c|}{ Between 0,8896 } & & \multicolumn{3}{|c|}{ Between 0,8395 } \\
\hline \multirow{4}{*}{ GLS Regresion } & ESD & Coef & $\mathbf{Z}$ & \multirow{4}{*}{ GLS Regresion } & ESD & Coef & $\mathrm{Z}$ \\
\hline & AYS & 1,0611 & 33,23 & & $\ln (\mathrm{AYS})$ & 1,3343 & 55,67 \\
\hline & $A Y S^{2}$ & $-0,0801$ & $-18,69$ & & Cons & 2,0551 & 52,3 \\
\hline & Cons & 1,0449 & 19,11 & & & & \\
\hline \multirow{4}{*}{ Within Regression } & ESD & Coef & $\mathrm{t}$ & \multirow{4}{*}{ Within Regression } & ESD & Coef & $\mathrm{t}$ \\
\hline & AYS & 1,0866 & 35,87 & & $\ln (\mathrm{AYS})$ & 1,3606 & 57,81 \\
\hline & $A Y S^{2}$ & $-0,0824$ & $-20,37$ & & Cons & 2,0441 & 84,1 \\
\hline & Cons & 1,0026 & 20,33 & & & & \\
\hline \multirow{4}{*}{ Between Regression } & ESD & Coef & $\mathrm{t}$ & \multirow{4}{*}{ Between Regression } & ESD & Coef & $\mathrm{t}$ \\
\hline & AYS & 0,3189 & 1,60 & & $\ln (\mathrm{AYS})$ & 0,9872 & 11,43 \\
\hline & $A Y S^{2}$ & $-0,0132$ & $-0,46$ & & Cons & 2,3574 & 29,6 \\
\hline & Cons & 2,0963 & 8,30 & & & & \\
\hline
\end{tabular}

Table 9 - Abbreviation of States

\begin{tabular}{|c|c|c|}
\hline Regions & States & Abbreviation \\
\hline \multirow{6}{*}{ Norte } & Acre & $\mathrm{AC}$ \\
\hline & Amapa & AP \\
\hline & Amazonas & $\mathrm{AM}$ \\
\hline & Para & $\mathrm{PA}$ \\
\hline & Rondonia & RO \\
\hline & Roraima & $\mathrm{RR}$ \\
\hline \multirow{5}{*}{ Centro Oeste } & Distrito Federal & DF \\
\hline & Goias & GO \\
\hline & Mato Grosso & MT \\
\hline & Mato Grosso do Sul & MS \\
\hline & Tocantins & TO \\
\hline \multirow{4}{*}{ Sudeste } & Espiritos Santos & ES \\
\hline & Minas Gerais & MG \\
\hline & Rio de Janeiro & $\mathrm{RJ}$ \\
\hline & São Paulo & SP \\
\hline \multirow{3}{*}{ Sul } & Parana & PR \\
\hline & Rio Grande do Sul & $\mathrm{RS}$ \\
\hline & Santa Catarina & SC \\
\hline \multirow{9}{*}{ Nordeste } & Alagoas & $\mathrm{AL}$ \\
\hline & Bahia & BA \\
\hline & Ceara & $\mathrm{CE}$ \\
\hline & Maranhão & MA \\
\hline & Paraiba & $\mathrm{PB}$ \\
\hline & Pernambuco & $\mathrm{PE}$ \\
\hline & Piaui & PI \\
\hline & Rio Grande do Norte & $\mathrm{RN}$ \\
\hline & Sergipe & SE \\
\hline
\end{tabular}

